Int. J. Agril. Res. Innov. Tech. 10(2): 170-176, December 2020 Available online at https://ijarit.webs.com DOI: https://doi.org/10.3329/ijarit.v10i2.51591 https://www.banglajol.info/index.php/IJARIT

\title{
Socioeconomic characteristics and constraints of participatory pond fish farmers in Mymensingh district, Bangladesh
}

\author{
M.N.A.S. Mithun*, M.S. Kowsari and S. Sheheli \\ Received 31 October 2020, Revised 17 December 2020, Accepted 24 December 2020, Published online 31 December 2020
}

\begin{abstract}
A B S T R A C T
The study was conducted to determine the socioeconomic characteristics and constraints of participatory pond fish farmers in Muktagachha upazila (sub-district) under Mymensingh district of Bangladesh. Data were collected by using a structured interview schedule during 01 to 31 October 2018 from a sample of 100 fish farmers (50\% of total population) who were selected randomly from a population of 200. Data were analyzed using descriptive statistics, rank order and coefficient of correlation. The majority of the participatory pond fish farmers (90\%) faced medium to low constraints. Among 22 constraints, lack of training on aquaculture was identified as the most critical one, followed by high price of various inputs. The least important constraint of the farmers was crisis of water in dry season. It was revealed that fish farming experience, annual family income and training exposure were significantly associated with the constraints of participatory pond fish farmers. It is therefore recommended that the Department of Fisheries (DOF) and other related organizations can offer credit facilities, proper training and suitable extension services to minimize the constraints of participatory pond fish farmers and meet the increasing demand of fish in Bangladesh.
\end{abstract}

Keywords: Pond fish farmer, Characteristics, Constraints, Participatory, Bangladesh.

Dept. of Agricultural Extension Education, Bangladesh Agricultural University, Mymensingh, Bangladesh.

*Corresponding author's email: nuralom38764@bau.edu.bd (M.N.A.S. Mithun)

Cite this article as: Mithun, M.N.A.S., Kowsari, M.S. and Sheheli, S. 2020. Socioeconomic characteristics and constraints of participatory pond fish farmers in Mymensingh district, Bangladesh. Int. J. Agril. Res. Innov. Tech. 10(2): 170-176. https://doi.org/10.3329/ijarit.v10i2.51591

\section{Introduction}

Bangladesh has favorable resources along with agro-climatic conditions, which makes it one of the more suitable countries for fish farming (Shamsuzzaman et al., 2020; Ahmed et al., 2012). Bangladesh is blessed with the world's largest flooded wetland and considered as the third largest aquatic biodiversity in Asia after China and India (Shamsuzzaman et al., 2016).

Bangladesh is one of the world's leading fish producing countries with a total farming of 42.77 lakh metric ton, where aquaculture farming contributes $56.24 \%$ of the total fish farming (DOF, 2018). Bangladesh ranked $3^{\text {rd }}$ in inland open water capture production and $5^{\text {th }}$ in world aquaculture production (FAO, 2018). Fish supplements about $60 \%$ of Bangladeshi people's daily animal protein intake (DOF, 2018). Fish is a popular complement to rice in the national diet, giving rise to the adage Maache-Bhate Bangali (a Bengali is made of fish and rice) (Ghose, 2014).

Fish farming in Bangladesh is an essential agricultural sub-sector, which plays an important role in its national economy (FRSS, 2017). More than $11 \%$ of the population directly or indirectly dependent on the fisheries sector for continuing their livelihood (DOF, 2016). A large number of people have improved their socioeconomic conditions through fish farming activities in Bangladesh (Ara, 2005). The fisheries sector contributes $3.61 \%$ to the Gross Domestic Product (GDP) of the country and $24.41 \%$ to the agricultural GDP (DOF, 2017). Besides an economic contribution, fish farming contributes to food security as a major source of animal protein (DOF, 2018; Khan et al., 2018).

Over last two decades, to meet the increasing foreign demands of fish and fishery product, aquaculture has expanded tremendously (Rana, 2016). Ponds cover only $3.5 \%$ of the total inland water of Bangladesh whereas they contribute about $31 \%$ of the total inland fish production thus playing a vital role in fresh water fish production (DOF, 2017). About 52.92\% of total fish production comes from inland culture. The areas 
of inland open water body, inland closed water body and pond are 3.92, 0.77 and 0.37 million hectares, respectively (DOF, 2017). But, the farming of inland open water is decreasing day by day (Sheheli et al., 2019). In this situation, to meet the increasing demand of fish in Bangladesh, improvement of participatory pond fish culture is essential.

Now-a-days, participatory pond fish farming has been proved a profitable and smart business comparing to the rice or other agricultural cultivations (Das et al., 2018). The production from participatory pond is increasing very sharply due to dissemination of adaptive technologies such as Tilapia, Koi, Magur, Shing, Pungas, Sarputi, Rui, Catla, Mrigel etc. through effective extension services by the Department of Fisheries, government and non-government organizations (Sheheli et al., 2019).

However, during participatory pond fish farming, the farmers of the study area usually face some constraints associated with it. Although, a large number of people are involved in participatory pond fish farming in that area, no specific study on the emerging constraints is reported yet.
Therefore, the researchers undertook this research keeping in mind the following objectives: to describe the socioeconomic characteristics of the fish farmers; to determine the constraints of participatory pond fish farmers; and to explore the relationships between socioeconomic characteristics and constraints of participatory pond fish farmers.

\section{Methodology}

\section{Study area}

The study was carried out in Kheruajani union of Muktagachha upazila (sub-district) under Mymensingh district of Bangladesh (Fig. 1). The Upazila located between $24^{\circ} 75^{\prime}$ and $24^{\circ} 83^{\prime}$ North latitudes and between $90^{\circ} 26^{\prime}$ and $90^{\circ} 67^{\prime}$ East longitudes. A huge number of farmers are involved with fish farming and have received extension services from Department of Fisheries (Sheheli et al., 2013). Good communication facilities and consequently less expense for conducting the study and researchers' perception about better cooperation from the fish farmers motivated the researchers to select the study area.

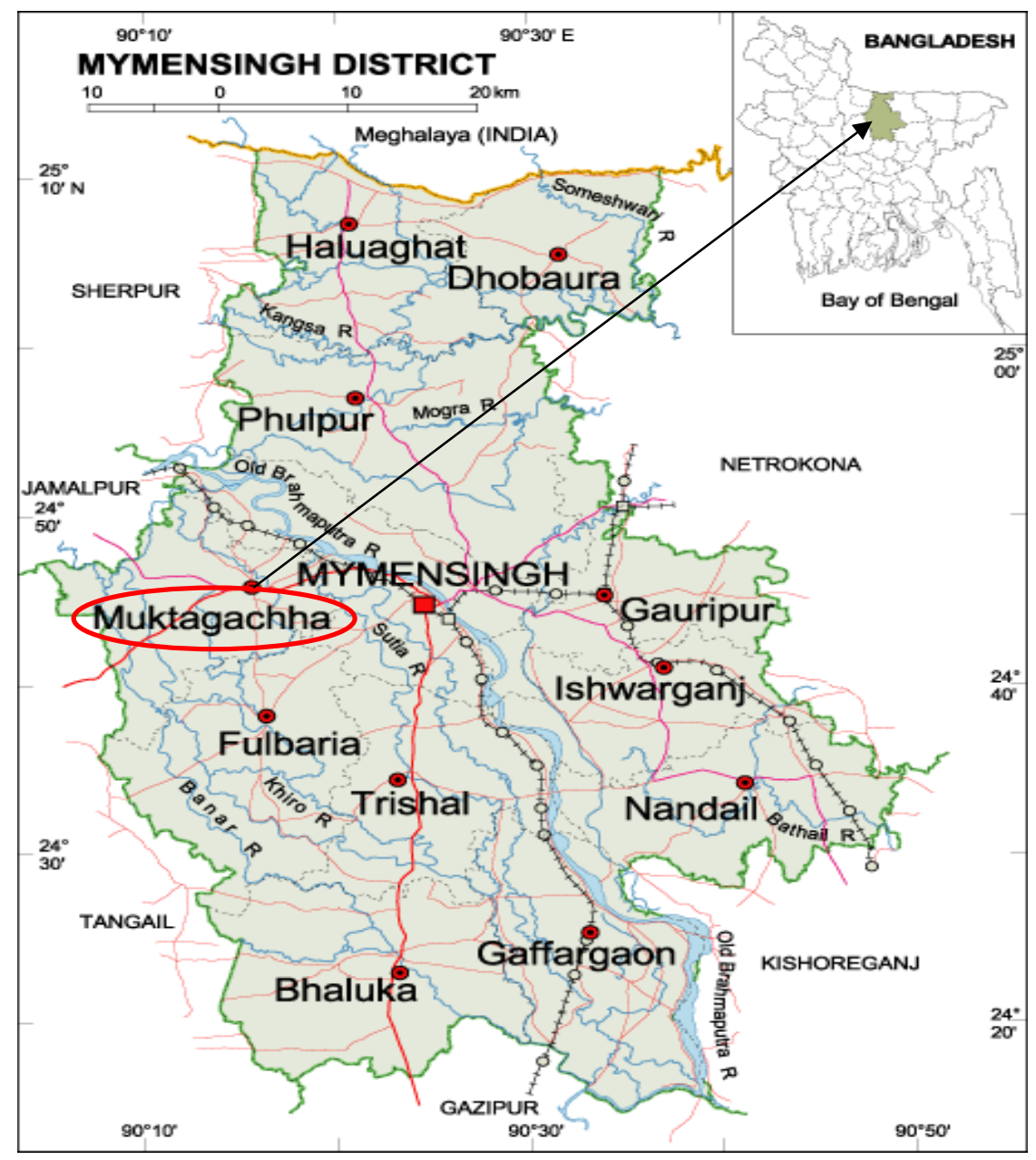

Fig. 1. Map showing the study area. 
Method of data collection and analysis of data

A total of 100 fish farmers $(50 \%$ of total population) were selected randomly from a population of 200 fish farmers which constituted the sample of this research. Data were collected by using a structured interview schedule through face to face interview with the selected fish farmers during 01 to 31 October 2018. Extent of constraints of participatory pond fish farmers was the focus variable and eleven socioeconomic characteristics of the fish farmers were selected as explanatory variables namely age, level of education, household size, farm size, area under fish farming, fish farming experience, annual family income, training exposure, extension media contact, organizational participation and knowledge on fish farming. The study identified 22 major constraints of participatory pond fish farmers.

The major constraints of participatory pond fish farmers were measured by using a 4-point rating scale (Islam et al., 2013). The respondents were asked to rate each problem as high, medium, low and not at all, with corresponding score of $3,2,1$ and $\mathrm{o}$, respectively. Thus, the constraint scores ranged from 0 to 66 , where 0 indicates no constraint and 66 indicates severe constraint. Moreover, a constraint facing score (CFS) was employed to identify the critical constraints in participatory pond fish farming (Equation 1). Other researchers (Amin et al., 2016; Pandit and Basak, 2013) also used similar formula to identify the critical constraints in their respective studies.

$$
\begin{aligned}
C F S=(\mathrm{Ph} \times 3) & +(\mathrm{Pm} \times 2)+(\mathrm{Pl} \times 1) \\
& +(\mathrm{Pn} \times 0) \ldots \ldots \ldots \ldots \ldots
\end{aligned}
$$

Where, CFS $=$ Constraint Facing Score, $\mathrm{Ph}=$ Number of responses with high constraints, $\mathrm{Pm}=$ Number of responses with medium constraints, $\mathrm{Pl}=$ Number of responses with low constraints and $\mathrm{Pn}=$ Number of responses with no constraint.

Thus, the CFS of individual constraint could range from $\mathrm{o}$ to 300 , where $\mathrm{o}$ indicating no constraint and 300 indicating high constraint of participatory pond fish farmers.

The Statistical Package for Social Sciences (SPSS) version 20 and Microsoft Excel version 13 was used for data management. Descriptive statistics, for instances, frequency, percentage, mean, standard deviation and rank order were used for categorization and describing the variables. Pearson's Product Moment Correlation coefficient (r) was used for testing the relationship between the socioeconomic characteristics and constraints of participatory pond fish farmers (Equation 2).

$r_{x y}=\frac{\sum\left(x_{i}-\bar{x}\right)\left(y_{i}-\bar{y}\right)}{\sqrt{\sum\left(x_{i}-\bar{x}\right)^{2} \sum\left(y_{i}-\bar{y}\right)^{2}}}$

Where,

$r_{x y}=$ Pearson's product-moment correlation coefficient

$\bar{x}$ and $\bar{y}=$ Means of the variables $x$ and $y$, respectively

\section{Results and Discussion}

\section{Socioeconomic characteristics of the fish farmers}

In this section, summary of the socioeconomic characteristics of the fish farmers have been presented in Table 1. The findings revealed that the majority (90\%) of the fish farmers were young to middle aged and maximum of them (65\%) had primary to secondary education. Fish culture requires technicalities regarding the use and management of instruments (Olaoye et al., 2013), where education can play a significant role in enabling farmers' understanding of technicalities as well as constraints resolution. Most of the fish farmers (80\%) were belong to medium to large sized family and the highest proportions (90\%) of them had small to medium sized farm. The majority of the fish farmers (62\%) mainly used their small sized farm area for fish culture and most of them (86\%) had medium to high income. Maximum of the fish farmers (75\%) had medium to high farming experience. Farmers with high experience can predict farm production and market situation (Olaoye et al., 2013). Majority of the farmers (59\%) received no training on aquaculture, followed by short duration training (37\%) and the highest proportions (86\%) of them had low to medium extension contact. Access to extension providers renders good sources of information for diversified farm activities (Odini, 2014). The highest proportions of the farmers (85\%) had low to medium organizational participation and most of them (98\%) had high knowledge on fish farming for increasing their fish production level. 
Table 1. Characteristics profile of the respondents $(n=100)$.

\begin{tabular}{|c|c|c|c|c|}
\hline Socio-economic characteristics & Frequency & Percentage & Mean & $\mathrm{SD}^{*}$ \\
\hline \multicolumn{5}{|l|}{ Age (year) } \\
\hline Young (18-35) & 35 & 35 & \multirow{3}{*}{$37 \cdot 95$} & \multirow{3}{*}{9.84} \\
\hline Middle age (36-50) & 55 & 55 & & \\
\hline Old $(>50)$ & 10 & 10 & & \\
\hline \multicolumn{5}{|l|}{ Level of education (year) } \\
\hline Illiterate (o) & 08 & 08 & \multirow{5}{*}{8.05} & \multirow{5}{*}{3.65} \\
\hline Can sign only (0.5) & 15 & 15 & & \\
\hline Primary $(1-5)$ & 30 & 30 & & \\
\hline Secondary (6-10) & 35 & 35 & & \\
\hline Higher secondary $(>10)$ & 12 & 12 & & \\
\hline \multicolumn{5}{|l|}{ Household size (number) } \\
\hline Small (up to 4) & 20 & 20 & \multirow{3}{*}{6.37} & \multirow{3}{*}{1.76} \\
\hline Medium (5-6) & 56 & 56 & & \\
\hline Large $(>6)$ & 24 & 24 & & \\
\hline \multicolumn{5}{|l|}{ Farm size (ha) } \\
\hline Landless(0.02 ha) & 0 & 0 & \multirow{5}{*}{1.52} & \multirow{5}{*}{1.02} \\
\hline Marginal(.02-0.2 ha) & 0 & 0 & & \\
\hline Small (0.21-1 ha) & 55 & 55 & & \\
\hline Medium (1.01-3 ha) & 35 & 35 & & \\
\hline Large (>3 ha) & 10 & 10 & & \\
\hline \multicolumn{5}{|l|}{ Area under fish farming (ha) } \\
\hline Small ( up to $1 \mathrm{ha}$ ) & 62 & 62 & \multirow{3}{*}{1.13} & \multirow{3}{*}{0.88} \\
\hline Medium (1.01-3 ha) & 33 & 33 & & \\
\hline Large (> $3.01 \mathrm{ha})$ & 5 & 5 & & \\
\hline \multicolumn{5}{|l|}{ Annual family income (“ooo” Tk.) } \\
\hline Low (up to 50) & 14 & 14 & \multirow{3}{*}{249.72} & \multirow{3}{*}{310.09} \\
\hline Medium (51-8o) & 56 & 56 & & \\
\hline High $(>80)$ & 30 & 30 & & \\
\hline \multicolumn{5}{|l|}{ Fish farming experience (year) } \\
\hline Low ( up to 15) & 25 & 25 & \multirow{3}{*}{$13 \cdot 31$} & \multirow{3}{*}{8.44} \\
\hline Medium (16-30) & 45 & 45 & & \\
\hline High $(>30)$ & 30 & 30 & & \\
\hline \multicolumn{5}{|l|}{ Training exposure (days) } \\
\hline No training (o) & 59 & 59 & & \\
\hline Short duration (up to 5) & 37 & 37 & & \\
\hline Long duration ( > 5) & 04 & 04 & 16.42 & 16.24 \\
\hline $\operatorname{High}(>9)$ & 15 & 15 & & \\
\hline Extension media contact (score) & & & & \\
\hline Low ( $0-9)$ & 31 & 31 & & \\
\hline Medium (10-18) & 55 & 55 & 7.42 & 3.66 \\
\hline High $(>18)$ & 14 & 14 & & \\
\hline Organizational participation (sc & & & & \\
\hline Low（ up to 5) & 59 & 59 & & \\
\hline Medium (5-8) & 31 & 31 & 2.16 & 1.95 \\
\hline High $(>10)$ & 10 & 10 & & \\
\hline Knowledge on fish farming (sco & & & & \\
\hline Low (up to10 ) & oo & oo & & \\
\hline Medium (11-20) & 02 & 02 & 25.22 & 2.44 \\
\hline High $(>20)$ & 98 & 98 & & \\
\hline
\end{tabular}

$S D^{*}$ stands for Standard Deviation

\section{Extent of constraints of participatory pond fish farmers}

The extent of constraints of participatory pond fish farmers has been presented in the Fig. 2. The findings reveal that more than half of the respondents (68\%) faced medium constraints, while $10 \%$ and $22 \%$ of them faced high and low constraints, respectively. The findings lead to illustrate that the majority of the participatory 
pond fish farmers (90\%) faced medium to low constraints. Our findings are supported by the findings of Rahman et al. (2014), who indicated that the farmers faced medium to low constraints (91.3\%) in practicing small scale aquaculture in Thakurgaon district of Bangladesh.

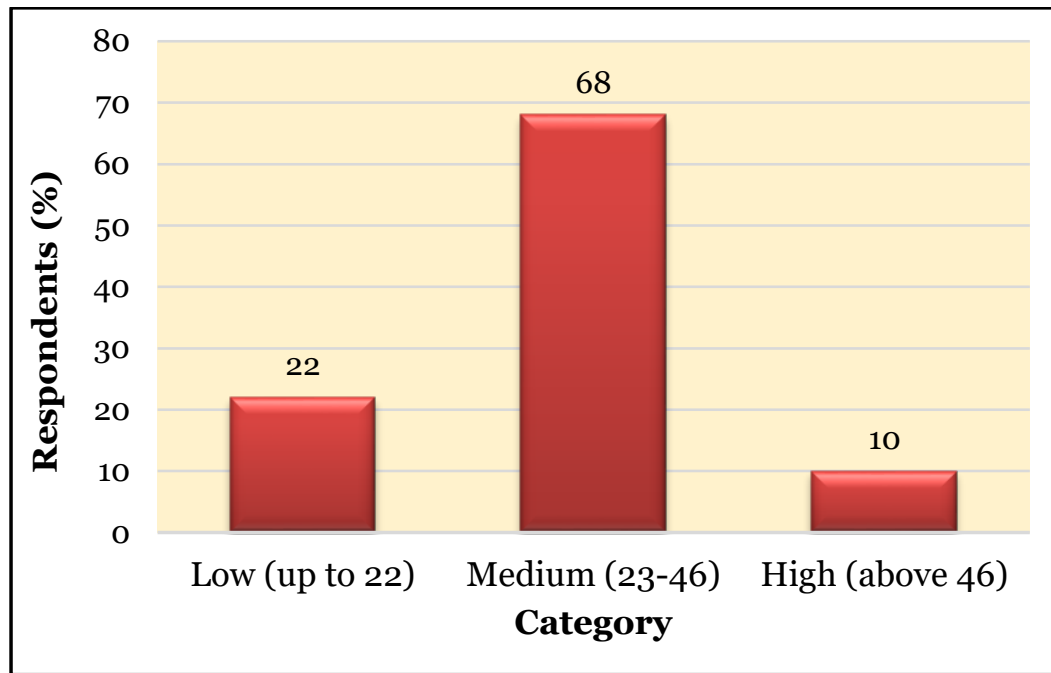

Fig. 2. Extent of constraints of participatory pond fish farmers $(n=100)$.

Table 2. Constraints of participatory pond fish farmers $(n=100)$.

\begin{tabular}{|l|c|c|c|c|c|c|}
\hline Constraints & \multicolumn{3}{|c|}{ Extent of constraints } & CFS & Rank \\
\hline & High & Medium & Low & Not at all & & order \\
\hline Lack of training on aquaculture & 60 & 30 & 10 & OO & 250 & 1 \\
\hline High price of various inputs & 65 & 21 & 11 & 03 & 248 & 2 \\
\hline Fear to start participatory farming & 60 & 30 & O5 & O5 & 245 & 3 \\
\hline Lack of preservation technology & 55 & 30 & 05 & 10 & 230 & 4 \\
\hline Poor transportation facilities & 45 & 40 & 10 & 05 & 225 & 5 \\
\hline Lack of marketing facilities & 55 & 20 & 15 & 10 & 220 & 6 \\
\hline Lack of skilled labor & 45 & 35 & 15 & 05 & 220 & 6 \\
\hline Lack of scientific and technical & 55 & 20 & 12 & 13 & 217 & 7 \\
\hline knowledge & & & & & & \\
\hline Security constraints (theft and animosity) & 50 & 25 & 15 & 10 & 215 & 8 \\
\hline Low profitability & 42 & 38 & 12 & 08 & 214 & 9 \\
\hline Adulteration of feed & 49 & 26 & 15 & 10 & 214 & 9 \\
\hline Lack of enough capital to invest & 40 & 40 & 10 & 10 & 210 & 10 \\
\hline Natural calamities (flood, drought) & 33 & 47 & 15 & 05 & 208 & 11 \\
\hline High interest on credit & 45 & 28 & 05 & 22 & 196 & 12 \\
\hline Fluctuation of market price & 35 & 35 & 20 & 10 & 195 & 13 \\
\hline Unavailability of quality fry & 36 & 34 & 18 & 12 & 194 & 14 \\
\hline Poor extension service & 35 & 35 & 15 & 15 & 190 & 15 \\
\hline Lack of credit facilities & 40 & 25 & 15 & 20 & 185 & 16 \\
\hline Land unavailability & 20 & 50 & 20 & 10 & 180 & 17 \\
\hline Disease occurrence & 40 & 20 & 20 & 20 & 180 & 17 \\
\hline Inbreeding constraint & 30 & 20 & 26 & 24 & 156 & 18 \\
\hline Crisis of water in dry season & 25 & 25 & 30 & 20 & 155 & 19 \\
\hline
\end{tabular}

CFS *: Constraint Facing Score

For determining the extent of individual constraint, a Constraint Facing Score (CFS) was computed and represented in Table 2. The findings show that lack of training on aquaculture was the most important constraints of fish farmers in participatory pond fish farming (CFS $=250$ ). Training enhances fish farmers' ability to manage farms and contribute maximum productivity of the farms efficiently and effectively (Ituma and Ukah, 2017). Training makes the trainee more qualified and fit to perform a task more effectively but in the study area, more than half of the fish farmers (59\%) received no training (Table 1). As a result, they faced many constraints in participatory pond fish farming. 
The high price of various inputs $(\mathrm{CFS}=248)$ was the second important constraints reported by the respondents. The farmers of the study area faced constraints of various inputs such as high price of fish feeds, chemicals and drugs for disease control, etc. Islam et al. (2013) found high price of fish feed as third ranked constraint in their research constraints as faced by the fish farmers in practicing semi-intensive climbing perch farming. Onemolease and Oriakhi (2011) and Rahman et al., (2014) reported high cost of fishing inputs as a major problem in fishing activities.
Fear to start participatory farming with a CFS score of 245 was reported as the third important constraints of fish farmers in participatory pond fish farming. Most of the fish farmers of the study area were afraid of starting participatory pond fish farming because of illiteracy, lack of experience, personal conflict, lack of motivation by the extension personnel, etc.

\section{Correlation between socioeconomic characteristics and constraints of participatory pond fish farmers}

Table 3. Result of correlation analysis between explanatory variables and focus variable.

\begin{tabular}{|l|l|c|}
\hline \multicolumn{1}{|c|}{ Focus variable } & \multicolumn{1}{|c|}{ Explanatory variables } & Correlation coefficient $(\mathrm{r})$ with $98 \mathrm{df}$ \\
& Age & -0.158 \\
\cline { 2 - 3 } & Level of education & 0.005 \\
\cline { 2 - 3 } $\begin{array}{l}\text { Constraints of } \\
\text { participatory pond fish }\end{array}$ & Household size & 0.115 \\
\cline { 2 - 3 } farmers & Farm size & -0.132 \\
\cline { 2 - 3 } & Area under fish farming & -0.113 \\
\cline { 2 - 3 } & Fish farming experience & $-0.38^{* *}$ \\
\cline { 2 - 3 } & Annual family income & $-0.288^{* *}$ \\
\cline { 2 - 3 } & Training exposure & $-0.237^{*}$ \\
\hline & Extension media contact & 0.018 \\
\hline & Organizational participation & -0.037 \\
\cline { 2 - 3 } & Knowledge on fish farming & -0.112 \\
\hline
\end{tabular}

Notes: **: Significant at 1\% level of probability; *: Significant at 5\% level of probability, df: Degrees of freedom

The negative significant correlation $(\mathrm{r}=-0.288)$ of annual family income with the constraints of participatory pond fish farmers clearly pointed out that the fish farmers having high income can minimize the undesirable loss during participatory pond fish farming. Azad et al. (2014) and Rahman (2011) found similar relationship between the concerned variables.

The training exposure had significant and negative relationship $(\mathrm{r}=-0.237)$ with the constraints of participatory pond fish farmers, indicating that training exposure enables farmers to manage their fish farming activities effectively. Islam et al. (2013), Rahman (2011) and Uddin et al. (2020) reported similar findings in their respective research.

\section{Conclusions}

The participatory pond fish farmers in the study area experience a number of constraints, of which, lack of training on aquaculture, high price of various inputs and fear to start participatory farming were significant. The degree of constraints is further determined by the socioeconomic characteristics of the farmers. Several factors such as fish farming experience, annual family income and training exposure of the fish farmers were found more influential to the constraints. This indicates an opportunity to work on those features to minimize the degree of constraints that lead to profitability in participatory pond fish farming. Therefore, it is highly recommended that the respective authority like Department of Fisheries should provide better interventions, like training and extension services, to the farmers in regard to participatory pond fish farming that would improve the profitability of fish production. Moreover, different credit organizations (both GOs and NGOs) should provide easily accessible credits to increase participatory pond fish farming within the study area.

\section{Acknowledgements}

The authors express their sincere gratitude to fish farmers and DOF in Mymensingh district, Bangladesh, for providing valuable information. Special thanks are extended to those people who helped under different capacities in this research.

\section{References}

Ahmed, N., Young, J.A., Dey, M.M. and Muir, J.F. 2012. From farming to consumption: a case study of tilapia marketing systems in Bangladesh. Aquac. Int. 20: 51-70. https://doi.org/10.1007/s10499-011-9441-0

Amin, M.A., Bashar, M.A., Akhter, N., Afroj, M., Islam, M.Z., Rahman, M.M. and Baque, M.A. 2016. Constraints faced by the farmers in IPM practices in rice cultivation. $J$. Sci. Technol. Environ. 4(1): 245-250. https://doi.org/10.18801/jstei.040116.27 
Ara, Y. 2005. Assessment of Small Scale Fresh Water Fish Farming for Sustainable Livelihoods of the Rural Poor Farmers. MSc Thesis. Department of Fisheries Management, Bangladesh Agricultural University, Mymensingh. pp. 1-17.

Azad, M.J., Ali, M.S., Islam, M.R., Yeasmin, M. and Pk, K.H. 2014. Problem Perceived by the Farmers in Vegetable Cultivation. J. Exp. Sci. 5(2): 63-68.

Das, M., Islam, M.R., Akter, T., Kawser, A.Q.M.R. and Mondal, M.N. 2018. Present status, constraints and prospect of fish farming at Gazipur Sadar upazila in Bangladesh. Progress. Agric. 29(1): 53-63. https://doi.org/10.3329/pa.v29i1.37480

DOF. 2016. Fishery Statistical Yearbook of Bangladesh. Fisheries Resources Survey System, Department of Fisheries, Ministry of Fisheries and Livestock, Dhaka, Bangladesh. pp. i-iv.

DOF. 2017. Fishery Statistical Yearbook of Bangladesh. Fisheries Resources Survey System, Department of Fisheries, Ministry of Fisheries and Livestock, Dhaka, Bangladesh. pp. 1-6.

DOF. 2018. Fishery Statistical Yearbook of Bangladesh. Fisheries Resources Survey System, Department of Fisheries, Ministry of Fisheries and Livestock, Dhaka, Bangladesh. pp. 1-9.

FAO. 2018. The State of World Fisheries and Aquaculture, Food and Agriculture Organizations of the United Nations, Rome, Italy. pp. 4-78.

FRSS. 2017. Fisheries Resources Survey System, Fisheries Statistical Report of Bangladesh, Department of Fisheries, Bangladesh. pp. 156.

Ghose, B. 2014. Fisheries and aquaculture in Bangladesh: Challenges and opportunities. Ann. Aquac. Res. 1(1): 1-5.

Islam, A.B.M.S., Farouque, M.G. and Roy, D. 2013. Constraint faced by the fish farmers in practicing semi-intensive climbing perch (Anabus testubineus) farming. Bangladesh J. Ext. Educ. 25(1\&2): 53-61.

Ituma, O.E. and Ukah, N.J. 2017. Training skill needs of secondary school agricultural science graduate in fish farming in Ebonyi state, Nigeria. Int. J. Bus. Manag. Soc. Res. 3: 186-191.

https://doi.org/10.18801/ijbmsr.030217.21

Khan, A.Q., Aldosari, F. and Hussain, S.M. 2018. Fish consumption behavior and fish farming attitude in Kingdom of Saudi Arabia (KSA). J. Saudi Soc. Agric. Sci. 17: 195-199.

https://doi.org/10.1016/j.jssas.2016.04.003

Odini, S. 2014. Access to and use of agricultural information by small scale women farmers in support of efforts to attain food security in
Vihiga County, Kenya. J. Emerg. Trends Econ. Manag. Sci. 5: 80-86.

Olaoye, O.J., Ashley-Dejo, S.S., Fakoya, E.O., Ikeweinwe, N.B., Alegbeleye, W.O., Ashaolu, F.O. and Adelaja, O.A. 2013. Assessment of socio-economic analysis of fish farming in Oyo state, Nigeria. Glob. J. Sci. Fron. Res. Agric. Vet. 13: 44-55.

Onemolease, E.A. and Oriakhi, H.O. 2011. Prospects and constraints of artisanal fishing in selected communities in Delta state, Nigeria. Adv. Appl. Sci. Res. 2: 55-61.

Pandit, J.C. and Basak, N.C. 2013. Constraints faced by the farmers in commercial cultivation of vegetables. J. Bangladesh Agril. Univ. 11(2): 193-198. https://doi.org/10.3329/jbau.v11i2.19893

Rahman, M. 2011. Constraint Facing of the Fish Farmers in Culturing Small Indigenous Sepcies. MSc Thesis. Department of Agricultural Extension Education, Bangladesh Agricultural University, Mymensingh. pp. 50-90.

Rahman, M.S., Roy, R.K. and Huda, S. 2014. Constraints and perceived scope for practicing small scale aquaculture in Thakurgaon District, Bangladesh. Bangladesh J. Ext. Educ. 26(1\&2): 97-106.

Rana, R. 2016. Use of Aqua-Drugs and Chemicals in Aquaculture of Manda and Niamatpur Upazila of Naogaon District. MSc Thesis. Department of Aquaculture, Bangladesh Agricultural University, Mymensingh. pp. 118.

Shamsuzzaman, M.M., Mozumder, M.M.H., Mitu, S.J., Ahamad, A.F. and Bhyuian, M.S. 2020. The economic contribution of fish and fish trade in Bangladesh Aquaculture and Fisheries. Aqua. Fish. 5(4): 174-181. https://doi.org/10.1016/j.aaf.2020.01.001

Shamsuzzaman, M.M., Xiangmin, X. and Islam, M.M. 2016. Legal status of Bangladesh fisheries: Issues and responses. Indian $J$. Mar. Sci. 45(11): 1474-1480.

Sheheli, S., Fatema, K. and Haque, S.M. 2013. Existing status and practices of fish farming in Trishal Upazila of Mymensingh District. Progress. Agric. 24: 191-201.

https://doi.org/10.3329/pa.v24i1-2.19172

Sheheli, S., Kowsari, M.S. and Mithun, M.N.A.S. 2019. Participatory pond fish production as an income generating activity: A farm level study. Bangladesh J. Ext. Educ. 31(1\&2): 163-170.

Uddin, M.N., Kabir, K.H., Roy, D., Hasan, M.T., Sarker, M.A. and Dunn, E.S. 2020. Understanding the constraints and its related factors in tilapia (Oreochromis sp.) fish culture at farm level: A case from Bangladesh. Aqua. 530: 735927.

https://doi.org/10.1016/j.aquaculture.2020. 735927 